Article

\title{
A New Approach to Partnerships for SDG Transformations
}

\author{
David Horan ${ }^{1,2}$ \\ 1 School of Politics and International Relations, Centre for Sustainable Studies and the Geary Institute for \\ Public Policy, University College Dublin, Dublin, Ireland \\ 2 Sustainable Development Solutions Network (SDSN), New York, NY 10115, USA; dgh2131@columbia.edu
}

Received: 17 May 2019; Accepted: 5 September 2019; Published: 10 September 2019

\begin{abstract}
Recent scientific reports highlight the urgent need for transformations to achieve the Sustainable Development Goals (SDGs) and long-term sustainability. This paper presents a new approach to partnerships that focuses on their role in transformations, the types of partnerships that may be needed and their enabling environment. It introduces transformation effectiveness as a criterion to evaluate a portfolio of partnerships and pathways as a tool to frame discussion of required partnerships. Guided by energy decarbonization and using a simple model of partnership formation, I highlight a (potential) mismatch between the types of partnerships required for transformation and the partnership types arising under the currently dominant voluntary approach. The model suggests the bottom-up approach can deliver some, but not all, of the partnerships needed. Five specific problems are identified-compensation for losers, partnering capacity, short-time horizons, inadequate coordination mechanisms and misaligned incentives. The paper then outlines some policy tools-transfers, regulation, public investment-governments could use to strengthen the bottom-up framework and orchestrate missing partnerships. The conclusion addresses two problems specific to the transformation approach: how to identify more systematically the partnerships needed (identification problem) and how to implement them (implementation problem); and outlines some ways to deal with these-science, deliberation, international leadership coalitions and frameworks/monitoring systems for transition partnerships.
\end{abstract}

Keywords: sustainable development; SDG transformations; means of implementation; partnerships; governance; governments

\section{Introduction}

Several recent scientific reports from international agencies highlight that global development is moving dangerously along the wrong path [1-7], and it is increasingly recognized that transformations are urgently needed in a range of areas to achieve the 2030 Agenda for Sustainable Development and long-term sustainable systems [8-13]. While many governments and societal stakeholders recognize the need for change and the importance of engaging each other in the process, there is a worrying lack of consensus in how to do this.

Much of the confusion revolves around the means of implementation (MoIs) and how to effectively engage different stakeholders in the process of transformation. This has been a long-standing stumbling block for sustainable development. In the 2030 Agenda, 62 of the 169 Sustainable Development Goal (SDG) targets are MoI targets [14], and the debate about SDG implementation is as much a debate about how to implement the MoIs [15]. In contrast to the Millennium Development Goals (MDGs), the MoIs were inter-governmentally negotiated and the document lists seven for achieving the SDGs: finance, technology, trade, capacity building, policy coherence, partnerships and data [15-18]. 
It is important to recognize that the history of sustainable development can largely be seen as a series of attempts to mobilize around a single focal MoI with other MoIs performing a secondary or tertiary role. Almost all these attempts relied on a narrow base of stakeholders, with little mention of systemic transformations. For example, in the 1990s, efforts to implement Agenda 21 centered on governments who primarily sought to address transnational environmental problems through policy coherence and international development through trade. These efforts informed new trade agreements and resulted in several United Nations (UN) conventions on deforestation, desertification, biodiversity, climate change, etc. Amidst weak government commitment to sustainable development, the Johannesburg Summit paved the way for a different approach based on voluntary transnational partnerships involving UN agencies, international organizations, donors and international non-governmental organizations (INGOs), with policy coherence receding to the background [19-21]. Meanwhile, during the MDGs, which primarily sought to address poverty in low-income countries, governments of low-income countries and NGOs operating there, prioritized finance, especially overseas development aid, with partnerships having a secondary role and capacity building a later tertiary role [22].

Despite notable successes, especially in poverty reduction, health and education [23,24], each attempt was ultimately undermined by well-documented failures in the mobilized MoI: weak government agreements, ineffective partnerships, insufficient development finance. Few countries gave $0.7 \%$ of Gross National Income (GNI). Many partnerships reported little or no activity [21]. Global climate agreements proved elusive for a long time [25], and inequitable trade agreements stirred discontent, protests and recently, populism [26-28].

The challenge today is to implement a more integrated approach to sustainable development that encompasses the seven means of implementation and new governance frameworks for enabling and managing systemic transformations. SDG transformations are seen as a way to organize the implementation of the SDGs $[10,29]$. These transformations seek to exploit synergies between Goals to achieve multiple SDGs by organizing implementation around SDG interventions that generate significant co-benefits [30]. The approach draws heavily on analyses that map out interdependencies between SDG outcomes [10,31,32]. For instance, The World in 2050 (TWI2050) research initiative-a collaboration between the UN Sustainable Development Solutions Network (SDSN), the International Institute for Applied Systems Analysis (IIASA), Stockholm Resilience Centre and Columbia University-proposes six transformations for achieving the SDGs and long-term sustainable systems: digital revolution; smart cities; energy decarbonization; sustainable consumption and production; sustainable food, biosphere and water, and human capacity and demography [9]. Similar proposals can be found in the forthcoming Global Sustainable Development Report, among others $[8,10,29,30]$. There is an emerging consensus at international level that such transformations require governments to adopt new governance frameworks, covering, for example, long-term integrated planning, new stakeholder engagement mechanisms, economic, social and political policies, aligned budgeting practices and procedures, among others $[8-10,29,30,33]$. New frameworks are required to address the enormous and complex governance challenges posed by sustainable development and systemic transformations [9].

The aim of this paper is to outline a new approach to partnerships that focuses on their role in transformations. It is recognized that partnerships may be an important part of transformations [34], however, the types of partnerships needed and the enabling environment for such partnerships has not previously been studied in detail. The main issues to address are the following: what types of partnerships are needed to achieve transformation, how can these partnerships be enabled and how can their success conditions be ensured.

The paper primarily focuses on the second issue, specifically, on evaluating the bottom-up approach to partnerships and identifying ways to improve it for transformation. It addresses the first issue: what types of partnerships are needed; only in a suggestive way, as some sense of what needed partnerships might look like is required for an analysis of how to enable them. More systematic ways to 
identify required partnerships, e.g., science, deliberation, and ways to ensure their success conditions are proposed in the concluding discussion.

A unique feature of partnerships is their potential to harness the MoI for transformation $[35,36]$. A variety of functions have been ascribed to partnerships [36-40]. In a recent study of 72 partnerships for energy decarbonization in urban China, Westman et al. [34] found evidence that partnerships perform a range of essential functions: from supporting technology development, demonstration projects and introducing technologies, to contributing to new policies, providing public infrastructure, and facilitating local climate action by creating access to data, technology and funding [34,41].

A second distinguishing feature of partnerships is their potential to achieve a more integrated approach to transformations [35]. Increasingly, studies highlight the different perceptions and interests of stakeholders in transitions [42]. The need for integrating perspectives to resolve overlapping transformations - sustainable and unsustainable-is recognized in the literature on socio-ecological transformations [12]. In particular, trade-offs that undermine other Goals have the potential to block transformation [43]. For instance, decarbonization is expected to directly target SDGs 3, 6, 7, 9, 11-15 and reinforce several other Goals $[29,44]$, yet, trade-offs could adversely affect fossil energy exporting regions (SDG 8.1), carbon-intensive industries and communities relying on fossil fuel industries (SDG 9.2) [43]. Examples such as the Just Transition Fund, that seeks to recreate economic opportunities for coal-mining communities, highlight how partnerships that combine conflicting stakeholders and synergistic SDGs, e.g., 4 and 9, can help to overcome trade-offs and facilitate transformation.

Few countries have any formal framework for enabling and ensuring effective partnerships [45]. Instead, countries are implicitly relying for the most part on a voluntary, bottom-up, self-enforcing and ad hoc approach to partnership formation [46,47]. At international level, the voluntary approach has dominated since the Johannesburg Summit, where it is better institutionalized via, for example, online registries, a voluntary reporting mechanism and guidelines for voluntary partnerships [19-21]. There is then a need to understand better whether a "laissez-faire" approach to partnerships can succeed in delivering the types of partnerships required for transformation and whether, and to what extent, partnerships may need to be orchestrated, and if so, which entity is most appropriate for orchestrating.

Previous studies of partnership effectiveness tend to focus either on individual partnerships, e.g., using case studies to explore their internal success conditions [48], or databases of partnerships, e.g., using descriptive statistics to examine their composition [19,34,36,49], output or overall impact $[40,50,51]$. A third, much less studied, approach focuses on the institutional environment for partnerships, relying on qualitative methods to assess principles, rules and institutions for enabling or ensuring effective partnerships [48,52-54].

This paper develops a model to assess the bottom-up approach to enabling partnerships and introduces transformation effectiveness as a new criterion for evaluating the effectiveness of a portfolio of partnerships. It uses the case of energy decarbonization to suggest types of partnerships that might be needed in different parts of the transformation. The method involves comparing two portfolios of partnerships, e.g., in terms of functions of partnerships, incentives of actors, etc., and assessing the overlap and mismatch between partnership types.

Drawing on a technical roadmap for energy decarbonization [55,56], some examples of partnerships that might be important include: partnerships with losers, e.g., fossil fuel producers, to overcome political obstacles, e.g., regulatory capture, to enable an appropriate policy environment for initiating transition; partnerships with surplus energy providers, e.g., fossil or renewable, domestic or foreign, to smooth transition, e.g., to decommission coal capacities, or to provide back-up capacity or network flexibility for intermittency problems; broad cross-sectoral partnerships for information sharing, agenda setting and finding solutions to sustainability problems; and long-term partnerships to scale-up promising solutions, e.g., deploying solar technology and building transmission lines.

The question I ask is whether these partnerships will be under-supplied in a bottom-up approach. To address this, a simple model of partnership formation is introduced in which partnerships arise only among actors who have an incentive to partner, the capacity to partner and some mechanism to 
coordinate the partnership into being, e.g., a conference or lead-partner. In the model, participation in partnerships is voluntary and self-enforcing.

Using this model, I indicate a (potential) mismatch between the types of partnerships required for transformation and those emerging under a bottom-up approach. Five specific problems are identified: compensation for losers; barriers to partnering; short-time horizons, inadequate coordination mechanisms and misaligned incentives. Specifically, the bottom-up approach has no in-built mechanism for enforcing transformative partnerships with strategic losers or building the partnering capacity of relevant stakeholders. It is unlikely to deliver long-term partnerships if relevant partners have short-time horizons. Required partnerships will not arise if there are information problems among potential partners and insufficient mechanisms for resolving them. In addition, bottom-up partnerships may not contribute to transformation, especially if participants have other incentives for partnering, such as reputational benefits. Anecdotal evidence and evidence from database studies is presented to support the prevalence of each of these problems [20,21,36,40].

Taken together, the five problems suggest a bottom-up approach to partnerships can only bring us so far towards transformation and increased mobilization of partnerships for transformation may be needed. The paper thus lends support to calls for better frameworks for partnerships $[18,45,52,57]$. It also contributes by increasing our understanding of factors that hinder partnerships and integrated approaches to transformation towards sustainability [12].

Several studies call for an "orchestrator" of partnerships. The debate centers on the role of the orchestrator and which entity should orchestrate. Most studies view orchestration as initiating and supporting individual partnerships. Proposed orchestrators include international institutions, government departments, [53,58-60], or professional orchestrators [61,62]. Other studies focus on the institutional environment and its governance, proposing government as "coordinating and integrating mechanism" [63], or assigning responsibility to the entity managing the partnership system, e.g., UN [64].

Each of the five problems offers a rationale for some entity to intervene to improve the bottom-up framework and suggests ways to better orchestrate partnerships. Although non-government actors can help alleviate these problems in a number of ways, the paper focuses on governments' role in mobilizing missing partnerships, whose unique assets: resources, policy capabilities, legitimacy, longer time-horizon; may be especially relevant if transformation requires the mobilization of partners and partnerships on a large-scale.

Policy instruments government could, in principle, use to address each problem are outlined. Some examples given, among others, include regulation or transfers to induce the participation in transformative partnerships of strategic losers and those lacking partnering capacity, public investments in partnering capacity, e.g., training facilities, and coordination mechanisms, e.g., dialogues, deliberative processes, matching infrastructure, etc., and the use of fiscal policy to restructure incentives for long-term partnerships.

How much government can improve frameworks for transformations is, of course, debatable. This issue, as well as issues with compensating transfers, have been discussed extensively elsewhere in economics and related disciplines [12,65-69]. The paper concludes by discussing two problems specific to the transformation approach: how to identify—-more systematically—partnerships needed (identification problem) and how to implement them (implementation problem), suggesting ways to address these-roles for science, deliberation, leadership coalitions and frameworks/monitoring systems for transition partnerships. The paper also suggests progressive governments, those less captured by losers and those leading on the SDGs, should improve partnership frameworks and orchestrate missing partnerships. 


\section{Partnerships in the 2030 Agenda for Sustainable Development}

Before proceeding, it is important to clarify what is meant by partnerships and how their basic links to sustainable development have been understood. The next section will reconceptualize the role of partnerships in terms of achieving transformations.

The 2030 Agenda refers to two main types of partnerships for implementing the SDGs. First, there is the Global Partnership for Sustainable Development, to be led by governments, which is seen as a vehicle for improving international cooperation for implementation of the 2030 Agenda $[15,16]$. It aims to "bring together governments, civil society, the private sector, the UN system and other actors to facilitate an intensive global engagement around implementation and mobilizing all available resources" [15].

Second, multi-stakeholder partnerships, to complement the Global partnership, are seen as important for strengthening the means of implementation, i.e., the aim of these partnerships is "to mobilize and share knowledge, expertise, technology and financial resources to support the implementation of the SDGs" [15]. These partnerships may be global, regional, national or subnational in terms of participating partners or focus of implementation.

Multi-stakeholder partnerships are not precisely defined in the 2030 Agenda, which focuses more on the Global Partnership. The UN resolution “Towards Global Partnerships" defines them as "collaborative relations between various parties, both public and non-public, in which all participants agree to work together to achieve a common purpose or undertake a specific task and, as mutually agreed, to share risks and responsibilities, resources and benefits" [70]. In the academic/expert literature, one common definition defines them as intersectoral collaborations between parties from two or more sectors, e.g., state, business, civil society, that strive to contribute to a sustainability goal $[35,59,71]$.

Regardless of the intended definition, the 2030 Agenda views the two types of partnerships as distinct, yet indispensable to each other. SDG 17 and the targets 17.16 and 17.17 call for an enhanced Global Partnership and more effective public, public-private and civil society partnerships. The Global Partnership is really about solidarity, cooperative action and the governance of sustainable development. The SDGs are then to be achieved through a "partnership of partnerships" or global system of partnerships [36].

There are two basic ways partnerships are understood to matter for sustainable development [39]. First, partnerships are needed to implement a more integrated approach to sustainable development problems, i.e., "the complex character of sustainability problems demands the active involvement of all societal spheres to resolve them" [35] (p. 76). Based on a recent survey of partnerships registered in the UN Department of Economic and Social Affairs (UNDESA) online platform, with a $25 \%$ response rate, Figure 1 indicates the additional value partnerships report to make towards SDG implementation [36].

Second, partnerships are required to harness the means of implementation and to promote a unified approach to sustainable development, i.e., "sustainable development stresses the need for mutual attainment of social equity, environmental health and economic wealth, for which the responsibilities and resources are allocated to different societal spheres" [35] (p. 76). Figure 2 indicates the role partnerships report in harnessing the MoI for the SDGs [36].

Based on available evidence, it is not possible to determine whether there is a gap in partnerships for SDG implementation or which partnerships should be orchestrated [36]. The same problem arises for partnership counts by SDG $[36,50]$. This paper will focus on assessing the bottom-up approach to partnerships and whether, and to what extent, partnerships for transformations need to be orchestrated. 


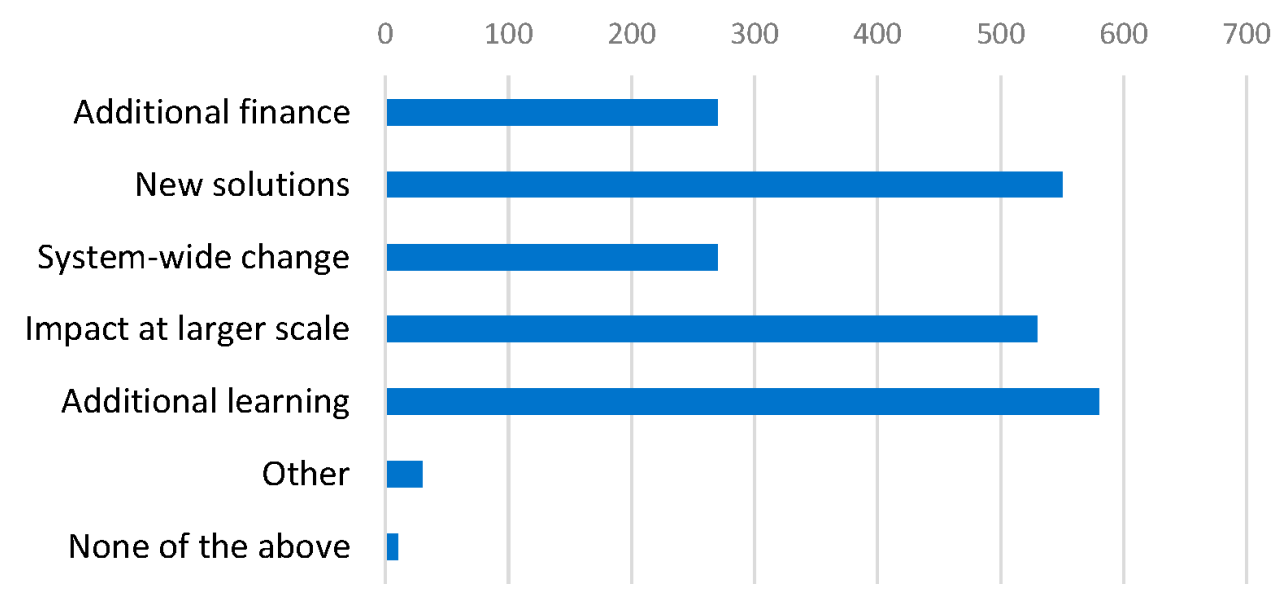

Figure 1. Additional Impact or Value of Partnerships that Partners Could not Generate Alone ( $\mathrm{n}=867)$ : Source [36]. Data pertains to a survey of partnerships registered on the UNDESA Partnerships for Sustainable Development Goals (SDGs) Online Platform 2019. Response rate-25\%.

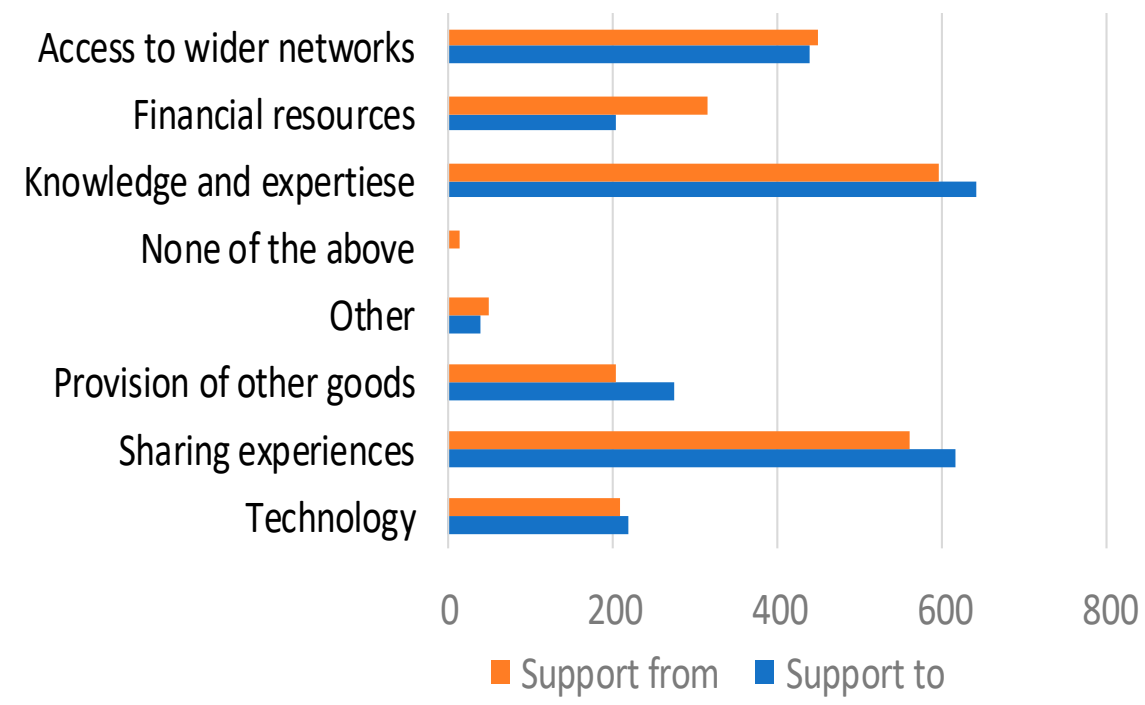

Figure 2. Support given $(n=876)$ and shared $(n=875)$ by lead organizations within partnerships. Source [36]. Data pertains to a survey of partnerships registered on the UNDESA Partnerships for SDGs Online Platform 2019. Response rate-25\%.

\section{Transformations: What Types of Partnerships May be Needed?}

To suggest partnerships for transformation, some insight can be gained from research on mitigation pathways, failures to implement climate policies and problems encountered with energy transition.

Transformations such as energy decarbonization are likely to be long-term initiatives, to require both deploying solutions and finding solutions to yet-to-be-solved problems, and to entail significant ex-ante uncertainty and distributional effects, e.g., generate winners and losers, affect differentially a range of stakeholders, current and future $[55,56,72-80]$. At the same time, transition needs to occur within a required time frame, i.e., the global energy system should halve its emissions by 2030 and achieve net zero emissions by 2050 [2]. Transition should be smooth, i.e., the energy system should continue to function robustly and reliably throughout [72,77]. It should be achieved in a cost effective and just manner, i.e., no stakeholder group should be left behind or unduly burdened [72,77-80].

Most research on mitigation pathways is based on integrated assessment models (IAMs) where levers and switches of change are policy and technology, and not partnerships [81-84]. These models are not suited to understanding the distribution of knowledge resources, institutional capacities, skills, 
perspectives and interests across stakeholders in a society. IAMs are helpful for mapping out the policy options, co-benefits of polices, etc. $[10,85,86]$, but they can't tell us how the different actors can most effectively combine to respond to these incentives. As suggested below, partnerships may be needed to put in place good policies.

Pathways or roadmaps can be a useful tool for framing discussions of partnerships needed. Without a roadmap, it is difficult to get a sense of what partnerships may be needed or how they might work together. Roadmaps give partnerships directionality, i.e., required partnerships will likely depend on which problems in the transition pathway require a partnership approach to address them, what functions the different partnerships should serve, which stakeholders need to be organized into partnerships, what chronology the partnerships should follow, how long they are needed for, etc. Important partnership functions may include broadening participation, information sharing, agenda setting, finding solutions, policy development and implementation, technology development and transfer, capacity building, making markets, sourcing funding, etc. [34,36-40].

This paper suggests partnerships may be needed to initiate a pathway or roadmap for transformation, to smooth transformation and to accelerate transformation. This view draws on a framework of Widerberg and Stipple [51]. In practice, to accelerate transformation, it is important to distinguish partnerships to deploy or scale-up potential solutions, and those that facilitate finding solutions to yet-to-be-solved problems. There may be considerable overlap. For example, The German Energiewende shows how transition tends to throw-up new problems, e.g., conflicts between species protection and expanding transmission networks, unexpected at the outset, and partnerships that integrate perspectives, e.g., coordinating government ministries, environmental NGOs, etc., may help to solve problems encountered [87]

The paper uses a technical roadmap for decarbonization, largely developed by engineers [56,88]. In a recent article, Jeffrey Sachs suggests,

"electricity should be become emission-free, through a combination of renewables (wind, solar, hydro), nuclear and perhaps some carbon capture and storage. Light-duty vehicles should become electric, and heavy-duty become electric, and heavy-duty trucks, ships and planes should run on some combination of zero-carbon fuels manufactured using clean energy". [72] (p. 2)

I focus primarily on decarbonizing electricity and partnerships to harness policy coherence and deploy or scale-up technologies. Such partnerships are important for mitigation [34], and not addressed by IAMs.

First, to initiate transformation, partnerships between winners and losers may be needed to build support and implement appropriate policies. For example, partnerships that compensate losers or give losers a stake in the future may be needed to overcome losers that use their incumbent positions, e.g., political influence, media connections, market power, to strategically block required changes, especially in areas of policy. This has almost certainly happened for climate policies, e.g., anti-climate activities of the U.S. fossil fuel lobby [88-91]. An example of a partnership to build support for transformation is the Just Transition Fund, which seeks to create economic opportunity for frontline communities and workers hardest hit by the transition away from coal [92]. Partnerships that give voice to unheard groups may also be important for ensuring policies developed and implemented are efficient and just, by limiting special interests pushing inefficient technologies, e.g., first-generation biofuels, or policies that unduly burden unrepresented groups, e.g., Yellow Vest movement [92].

Second, partnerships may be needed to smooth transformation, e.g., to ensure the energy system continues to function robustly in a way that facilitates low-carbon technologies. For example, partnerships with losers may be needed to provide back-up capacity to intermittency problems, to decommission coal capacities for their substitution by renewable energy, and to provide preferential grid access to green suppliers, e.g., feed-in-tariffs and compulsory purchase agreements [56]. Long-term partnerships may also be needed to build transnational transmission lines and ensure network flexibility 
across countries, e.g., for wind and solar [56]. While some examples of these partnerships exist, e.g., German Coal Exit Commission, Agreements between Norway and Sweden with Denmark, they are not mainstream and their effectiveness and scalability are questionable (e.g., Energiewende is characterized by hierarchical governance and uncoordinated ministries, hydro is not scalable) [87]. Better designed partnerships will likely be necessary to reduce committed emissions from existing energy infrastructure $[93,94]$, and to distribute renewables across parts of the world challenged by weaker governance structures and financial resources $[57,87,88]$.

Third, partnerships may be needed to accelerate transformation. For instance, to decarbonize electricity, a variety of technologies can be utilized whose relative merits are often contextual [56]. Broad participation partnerships may be needed for information sharing, agenda setting and policy development, e.g., Dutch Energy Agreement. To deploy selected technologies, long-term partnership may be needed to reduce the cost of finance, the cost of technology and to build relevant infrastructure e.g., the International Solar Alliance. To develop technologies, partnerships may be needed to create trading opportunities and markets $[95,96]$.

For this paper, motivating features of partnerships-winners and losers, long-term, broad participation-likely important for transformation are sufficient for assessing the bottom-up approach. However, for practical implementation and empirical evaluation, a key challenge is to identify, more precisely, the types of partnerships needed for transformation. This requires more systematic analysis and use of deliberative processes than presented here.

\section{The Need for a New Approach to Partnerships}

An important question is whether the enabling environment for partnerships can be reasonably expected to generate the types of partnerships needed for transformation. It is well known that most partnerships have been ineffective [46,49], and the literature on this uses several metrics and methods to assess effectiveness, e.g., progress updates, planned versus actual output, indicators of organizational capacity, resources and transparency, the number of partners from specific sectors $[21,36,46,97]$. The concern in this section is not to assess partnership effectiveness in a stand-alone sense, but to evaluate effectiveness relative to a required transformation.

At least two types of effectiveness are important for achieving a transformation. The first concerns the internal workings of a partnership and its ability to deliver its stated objectives. Research suggests that partnerships can be successful, but their success conditions are demanding and depend on several factors [64]. These include effective leadership, willingness of participants to invest time and resources, process management, the degree of institutionalization, adequate funding, adaptability to local conditions, etc. [21,48,64,98].

The second type, which I introduce here, is transformation effectiveness. Given an agreed pathway, transformation effectiveness concerns the extent of overlap or mismatch between types of partnerships required for transformation and types of partnerships that emerge from some enabling environment for partnerships. If there is no mismatch, the enabling environment is said to be effective. Otherwise, it is not transformation effective. The greater the extent of mismatch, the more ineffective the enabling environment for transformation. The analysis involves comparing two portfolios of partnerships, one required for transformation and one generated by some enabling environment and determining the extent of overlap between these portfolios.

The enabling environment that exists today took shape around the early millennium $[59,64]$. Felix Dodds recounts, "in the preparatory phase of the WSSD, a consensus emerged among the actors involved that traditional intergovernmental relations were no longer enough in the management of sustainable development and suggestions were incorporated for increasingly decentralized and participatory approaches known as Type II Partnerships" [59] (p. 6), see also [19,20]). Type II partnerships, which are meant to translate Type I political agreements into action, were characterized as "collaborations between national or sub-national governments, private sector actors and civil society 
actors, who form voluntary transnational agreements in order to meet specific sustainable development goals" [59].

The key word here is voluntary, it implies a bottom-up approach to partnership formation. This is akin to a market-based approach to partnerships. Voluntary partnerships rely on two or more actors having an incentive to partner [46,99], capacity to partner [100] and some entity or mechanism, formal or informal, to coordinate them. For example, the entity may be a lead-partner or the mechanism may be a UN conference, e.g., Oceans Conference, an important mechanism for registration in the Partnerships for SDGs online platform [97].

Why actors participate in a collaboration is complicated, depending on a range of factors, e.g., distribution of benefits, individual discount rates, trust, communication, culture, etc. For simplicity, I focus on two elementary rules of thumb. First, the stakeholders must somehow gain from the partnership and some of these gains should arise in the not too distant future. Second, the stakeholder must have the capacity to partner in the first place. Capacity could refer to the institution's resources, skills, time, etc., to partner [46]. I abstract from cultural and legal barriers to partnering. Therefore, the voluntary approach to partnership formation is dependent on the existence of win-win partnerships for participants, and those who partner must have the capacity to partner. Partnerships will tend to have a short-time horizon, which does not rule out long-term partnerships, but requires that the winnings a partner receives are compatible with individual discount rates.

There is no ex-ante guarantee such an approach generates partnerships for transformation. To start a transition and to ensure it is smooth, partnerships may need to be forged between winners and losers. It may also be important for just transition that those affected in a significant way have a voice in how transition is achieved [78-80,101-103], even if these actors have limited capacity to partner. The transition may require a range of long-term partnerships, for instance, to invest in capacity, e.g., transmission lines; to ensure finance, e.g., an adequately resourced Green Climate Fund; to deploy prioritized technologies, e.g., solar, wave, wind; to research and advance potential alternatives, e.g., carbon capture storage, alternative fuels etc.; and to maintain policy coherence, e.g., a carbon price or portfolio standards. The flow of costs and benefits from such partnerships may be relatively uniformly distributed across time in some cases or the distribution of benefits may be highly skewed towards the long-term, especially if the transition requires developing several early-stage technologies that are "far from the market".

If we accept these premises, some amount of partnerships between winners and losers and some amount of partnering with those lacking capacity to partner is needed. Some amount of long-term partnerships with significant short-term payoffs and some with only long-term payoffs are needed. Entities/mechanisms to coordinate these partnerships are also required.

Comparing the two portfolios of partnerships, the analysis suggests there are good reasons to believe the voluntary approach to partnerships is inappropriate as an environment for enabling partnerships for transformation. Figure 3 illustrates the (potential) mismatch between voluntary partnerships and partnerships for transformation. The number and types of partnerships will obviously depend on the specific transformation under consideration. 


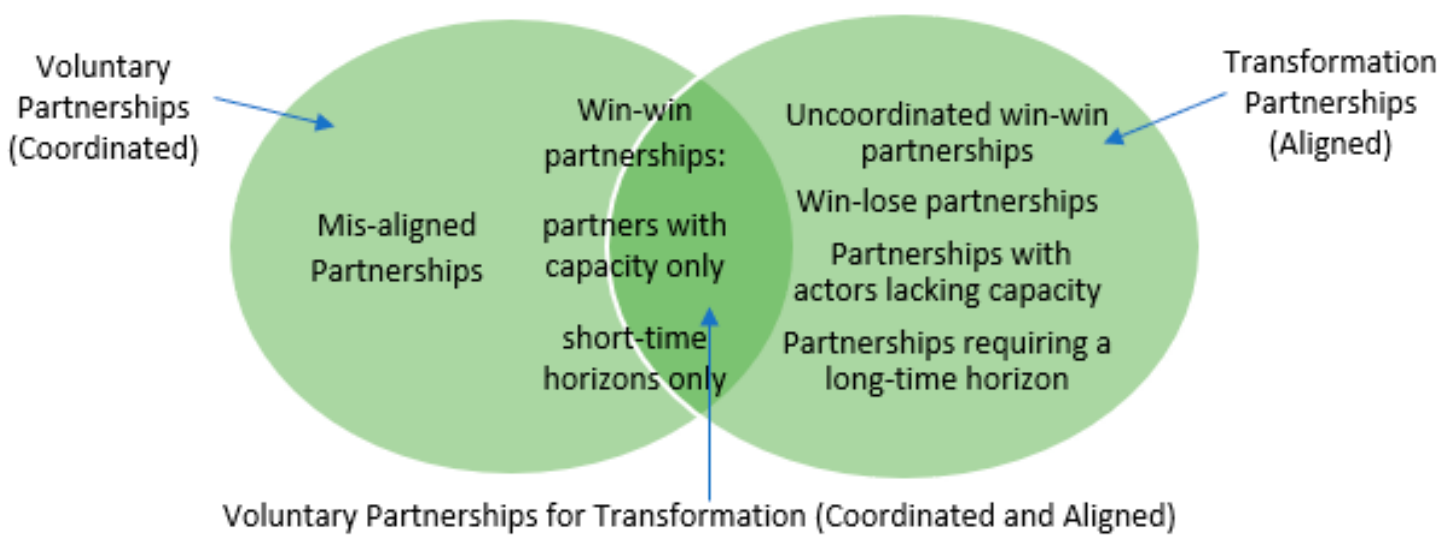

Figure 3. Mismatch and Overlap Between Voluntary Partnerships and Partnerships for Transformation.

On the one hand, the voluntary approach will generate self-enforcing win-win partnerships among those actors who have the incentive and capacity to partner. Overall, voluntary partnerships will tend to be skewed towards actors with short-time horizons. To the extent such partnerships are needed, there is an overlap with the set of transformation partnerships. The extent of overlap depends too on the private benefits of partnering being aligned to the social good of contributing to transition.

On the other hand, partnerships unlikely to be supplied under a voluntary approach include win-lose partnerships, partnerships with those lacking capacity to partner and partnerships requiring actors with long-time horizons, i.e., where net benefits are low until some future distant date. Further, there are win-win partnerships aligned to transformation that do not arise under the voluntary approach because they are not coordinated into being, for example, because of information problems, free-riding or the lack of an entity or mechanism to coordinate the potential partners.

Figure 3 suggests the extent of mismatch will increase if (1) more partnerships between winners and losers are needed, (2) more partnerships with those who lack the capacity to partner are needed, (3) more partnerships are needed involving actors with long-time horizons, and (4) more uncoordinated win-win transformation partnerships are needed. As outlined, there are good reasons to believe such partnerships are important for achieving energy decarbonization.

\section{Five Problems with the Voluntary Approach to Transformation Partnerships}

This section explores further the mismatch between voluntary and transformation partnerships. Based on the analysis of the previous section, it identifies five specific problems with the voluntary approach. Although not typically viewed through the lens of long-term transitions, some of these problems are well-known, whereas others identify issues not previously addressed.

Table 1 summarizes what is said on links between types of partnerships that may be needed for transformation and problems that could arise under a voluntary approach.

First, a core feature of transformations is winners and losers and partnerships with losers may be important to initiate and smooth transformation. For example, fossil fuel producers will lose out to renewable energy suppliers under decarbonization. Livestock farmers will lose out to fruit and vegetable suppliers in the planetary diet [11,89-91]. The voluntary approach to partnerships has no mechanism for incentivizing losers to participate in transformation. This I refer to as the compensation problem since this participation issue is essentially about incentive compatibility. Presumably, the losers from transitions will not seek to partner even though they often have the capacity to partner. They may act strategically to deter transition through lobbying, regulatory capture, and voting behaviors. They may also spread dis-information and create uncertainty about scientific evidence. The compensation problem helps explain the low partnering rates of the private sector, the anti-climate policy behaviors of the fossil fuel lobby, and the voting patterns of coal mining communities [20,36,88-91]. 
Table 1. Partnerships for Transformation and (Potential) Problems with a Bottom-up Approach.

\begin{tabular}{ccccc}
\hline Partnership Type & Transition Role & Possible Functions & Potential Problem & Supporting Evidence \\
\hline $\begin{array}{c}\text { Win-lose } \\
\text { Partnerships }\end{array}$ & $\begin{array}{c}\text { Initiate } \\
\text { Smooth }\end{array}$ & $\begin{array}{c}\text { Policy Coherence } \\
\text { Capacity Building } \\
\text { Making Markets }\end{array}$ & $\begin{array}{c}\text { Compensation for } \\
\text { Losers }\end{array}$ & $\begin{array}{c}\text { Lobbying, Voting } \\
\text { Regulatory Capture } \\
\text { Dis-information }\end{array}$ \\
\hline $\begin{array}{c}\text { Broad-participation } \\
\text { Partnerships }\end{array}$ & $\begin{array}{c}\text { Initiate } \\
\text { Facilitate } \\
\text { Just }\end{array}$ & $\begin{array}{c}\text { Information Sharing } \\
\text { Agenda Setting } \\
\text { Policy Development }\end{array}$ & $\begin{array}{c}\text { Partnering } \\
\text { Capacity }\end{array}$ & $\begin{array}{c}\text { Low Sectoral } \\
\text { Participation Rates }\end{array}$ \\
\hline $\begin{array}{c}\text { Long-term } \\
\text { Partnerships }\end{array}$ & $\begin{array}{c}\text { Smooth } \\
\text { Facilitate } \\
\text { Scale up }\end{array}$ & $\begin{array}{c}\text { Advance Early-stage } \\
\text { Technologies }\end{array}$ & $\begin{array}{c}\text { Short-time } \\
\text { Horizons }\end{array}$ & $\begin{array}{c}\text { High Discount Rates } \\
\text { Prence of Short-term } \\
\text { Partnerships }\end{array}$ \\
\hline $\begin{array}{c}\text { Win-win } \\
\text { Partnerships }\end{array}$ & Multiple & Multiple & Uncoordinated & $\begin{array}{c}\text { Few Mechanisms } \\
\text { Low Awareness }\end{array}$ \\
\hline $\begin{array}{c}\text { Win-win } \\
\text { Partnerships }\end{array}$ & None & None & $\begin{array}{c}\text { Misaligned } \\
\text { Incentives }\end{array}$ & $\begin{array}{c}\text { Low Reporting } \\
\text { Ineffective Partnerships }\end{array}$ \\
\hline
\end{tabular}

Second, there are several reasons why partnerships with those lacking capacity to partner may be important for transformation, including initiating transformation, facilitating new solutions, ensuring just transition, etc. The voluntary approach has no in-built mechanism for overcoming this barrier. I refer to this as the partnering capacity problem. This refers to stakeholders who should participate in a partnership but who lack capacity-representative's education, income and skills or the institution's resources and capacities—to represent themselves. Not all partners have such capacity, know how to partner or are present to partner. Examples include future generations, small NGOs, local stakeholder groups, etc.

The existence of barriers to partnering is well-recognized $[46,97]$ and supported by several database studies. Figure 4 shows the number of partners from specific sectors and major groups [20]. While this data pertains to Type II partnerships, there is no especially good reason to believe these problems do not persist for 2030 Agenda partnerships [36].

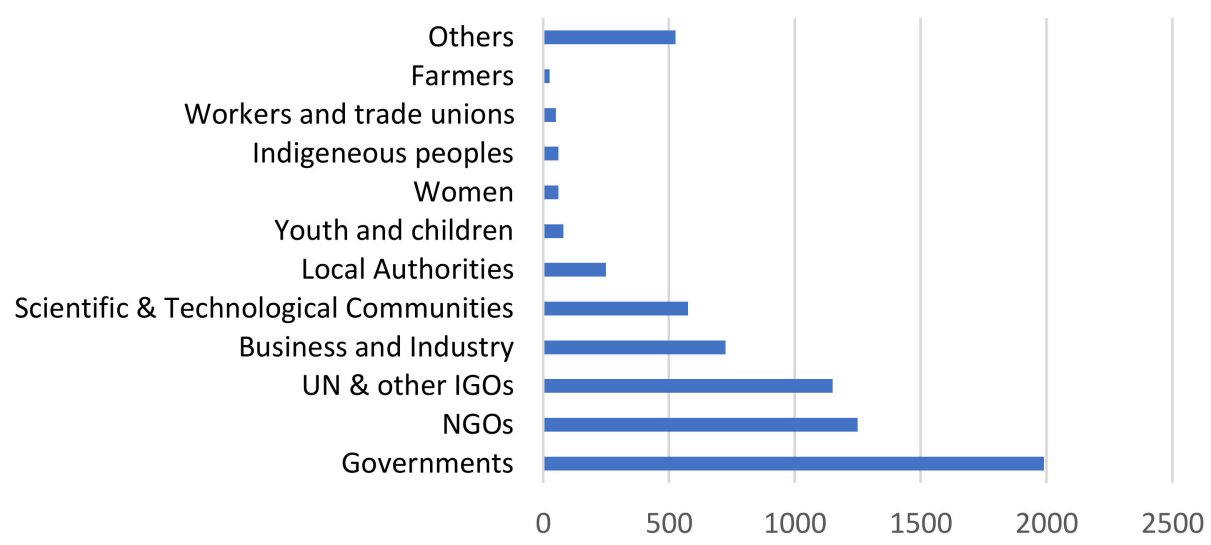

Figure 4. Number of Partners from Different Sectors and Major Groups. Source: Backstrand [20]. Data used pertains to Type II partnerships registered In the UN Commission for Sustainable Development database in 2006.

A common finding in such studies is that participation is biased towards donor governments, UN agencies, other international organizations and INGOs [36,50]. These organizations have well-recognized capacity to partner. In this sample, limited participation is observed by the private sector, research institutions, local authorities and grassroots groups. Among these, we have potential partners who either choose not to partner or who lack capacity to partner.

Third, voluntary partnerships are unlikely to be suitable for achieving long term-transitions if relevant actors have short-time horizons and achieving transformation requires partnerships that generate payoffs skewed towards the long-term. This I refer to as the horizon or discounting problem, since I am referring here to discount rates that are too high relative to what is required for 
collaboration. Decarbonization is expected to be a long-term initiative. Yet, many relevant actors, e.g., private companies, NGOs, universities, etc., tend have short-time horizons, e.g., possibly due to uncertainty over future revenue and funding streams. If transition partnerships require a broad range of stakeholders and any one of these stakeholders has a short horizon (i.e., high discount rate), then the partnerships will presumably not occur under a voluntary approach.

Fourth, there is the coordination problem. Win-win transformation partnerships may not occur for several reasons: information problems, whereby partners are not aware the partnership opportunity exists, or because of free riding problems, each potential partner is aware of the opportunity but is waiting for others to take the lead and pay the set-up costs of the partnership. Here, actors may have an incentive to partner and the capacity to partner but lack a mechanism to coordinate the partnership into being.

To overcome these problems, the bottom-up approach has generally relied on a small number of conferences and meetings, e.g., Oceans/SIDS Conferences, SIDS Partnership Dialogues, and the efforts and networks of a limited number of lead partners, e.g., UN agencies such as United Nations Development Programme (UNDP), United Nations Environment Programme (UNEP) and donor governments, to spin out partnerships [47,97]. In the case of information problems, low awareness of the SDGs, for example, in the United States, or the prevalence of siloed organizations, i.e., organizations with limited experience in cross-sectoral partnering, points to contexts where the coordination problem may be particularly severe.

Fifth, voluntary partnerships may not be aligned to transition, i.e., address problems required to achieve it. This I refer to as the mis-alignment problem. In some cases, this is an incentive problem, i.e., private incentives to partner (i.e., winnings) may diverge from the social benefits of achieving the transition, e.g., blue washing partnerships that advance special interests, e.g., by using the UN logo, but do not contribute to sustainable development [104]. In other instances, it could be a classification problem, i.e., the partnership contributes to societal wellbeing but not in a way that helps to achieve the required transformation.

Low reporting rates of partnerships, found on most partnership platforms, currently $16 \%$ in the Partnerships for SDGs Online Platform, and evidence that many partnerships are ineffective (see Figure 5), showing no output at all or output that does not match their stated objectives [21,40], points to the prevalence of misaligned partnerships [104].

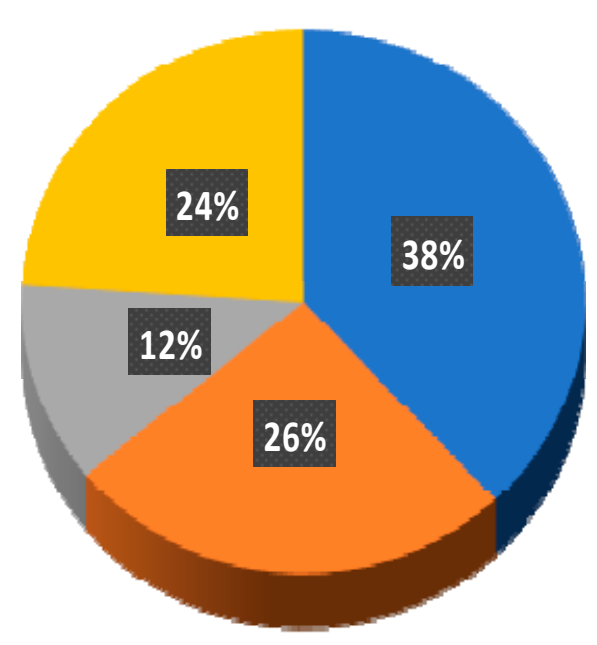

Partnerships show no
output at all
Output does not match
with self reported
function
Some of the output
matches with self-
reported function
All the output matches
with self-reported
function

Figure 5. Partnership output related to publicly stated goals and ambitions. Source [40]. Data pertains to the UN Commission for Sustainable Development Type II Partnerships (2012). 


\section{Policy Tools to Orchestrate Missing Partnerships}

Due to efficacy problems with partnerships [51,54], several recent studies call for an "orchestrator" to enable and guide partnerships, and much of the debate revolves around the precise role of the orchestrator and which entity should orchestrate [58-64,105-107]. Most of these studies focus on initiating and supporting individual partnerships and different ways to overcome collective action problems involving diverse actors, e.g., by convening stakeholders, contributing set-up costs, expertise, leadership, process management, trust building, etc. $[47,58,61,62]$. As the literature tends to view partnerships as alternative arrangements for transnational governance [108,109], most studies propose assigning the orchestration function to multilateral organizations or donor governments $[18,53,58-60,105]$, whereas other studies view orchestration as a professional activity to be undertaken by a secretariat, focal point or host $[64,65]$.

A different approach is to view partnerships as implementation instruments for transformations and to use economic techniques to shed light on problems associated with the voluntary approach and policy tools to deliver partnerships better tuned to transformation. For a required transformation, the main rationale for interventions to improve partnerships is to reduce failures associated with the voluntary approach. Given an agreed transition pathway, the objective should be, first, to enable a portfolio of partnerships to deliver the transition (transformation effectiveness), and, second, to ensure the success conditions of these partnerships (internal effectiveness).

This paper focuses on government interventions to strengthen the bottom-up framework and orchestrate missing partnerships. It outlines some policy instruments governments could, in principle, use to address each of the five problems. While other entities, e.g., UN agencies, international institutions, INGOs, businesses, universities etc., can help to alleviate these problems in a number of ways, e.g., through the provision of facilities, finance, networks, expertise, etc. This section suggests only governments have the resources, decision tools and legitimacy to mobilize stakeholders at a scale necessary for transformation.

Throughout, I assume that the correct portfolio of partnerships to implement transformation is known (in the next section, some strategies for identifying this portfolio are discussed). Society's distribution of organizations, institutional capabilities and skills is taken as given. The main problem is how policy could mobilize these resources for transformation. Table 2 summarizes what this section says on the links between problems associated with a voluntary approach and policy tools to orchestrate missing transformation partnerships.

Table 2. Partnerships for Transformation: (Potential) Problems and Policies.

\begin{tabular}{|c|c|c|c|c|}
\hline Partnership Type & Possible Functions & Potential Problem & Policy Tools & Possible Examples \\
\hline $\begin{array}{c}\text { Win-lose } \\
\text { Partnerships }\end{array}$ & $\begin{array}{l}\text { Policy Coherence } \\
\text { Capacity Building } \\
\text { Making Markets }\end{array}$ & $\begin{array}{l}\text { Compensation } \\
\text { for Losers }\end{array}$ & $\begin{array}{l}\text { Transfers } \\
\text { Debt Finance } \\
\text { Regulation }\end{array}$ & $\begin{array}{c}\text { Conditional Cash Transfers } \\
\text { Stock options, Retraining } \\
\text { Command and Control }\end{array}$ \\
\hline $\begin{array}{c}\text { Broad- } \\
\text { participation } \\
\text { Partnerships }\end{array}$ & $\begin{array}{l}\text { Information Sharing } \\
\text { Agenda Setting } \\
\text { Policy Development }\end{array}$ & $\begin{array}{c}\text { Partnering } \\
\text { Capacity }\end{array}$ & $\begin{array}{l}\text { Public Investment } \\
\text { Transfers }\end{array}$ & $\begin{array}{c}\text { Training Facilities } \\
\text { Professional Reps } \\
\text { Funds for Participating }\end{array}$ \\
\hline $\begin{array}{l}\text { Long-term } \\
\text { Partnerships }\end{array}$ & $\begin{array}{c}\text { Deployment } \\
\text { Advance Technology }\end{array}$ & $\begin{array}{l}\text { Short-time } \\
\text { horizons }\end{array}$ & $\begin{array}{c}\text { Transfers } \\
\text { Debt Finance }\end{array}$ & Inter-temporal Transfers \\
\hline $\begin{array}{c}\text { Win-win } \\
\text { Partnerships }\end{array}$ & Multiple & Uncoordinated & $\begin{array}{l}\text { Public Investment } \\
\text { Transfers }\end{array}$ & $\begin{array}{l}\text { Matching Platforms } \\
\text { Convening Infrastructure } \\
\text { Professional Orchestrators }\end{array}$ \\
\hline $\begin{array}{c}\text { Win-win } \\
\text { Partnerships }\end{array}$ & None & $\begin{array}{l}\text { Misaligned } \\
\text { Incentives }\end{array}$ & Regulation & Delist, Fine, Ban \\
\hline
\end{tabular}

Consider first the compensation problem. To increase the participation of losers in partnerships for transformation, governments have, in principle, two main policy instruments at their disposal: compensating transfers and regulation. The main idea behind the transfer approach is to create an incentive for losers to participate in, for instance, policy change, e.g., carbon tax, or capacity adjustment, e.g., decommission coal capacities, or making markets, e.g., preferential grid access to renewable 
suppliers. Similar compensating transfers have been proposed in the political economy literature of reform in transition economies, e.g., to buy the acceptance of insiders that stand to lose most from enacting reform [65].

These transfers could combine cash payments, stock options, e.g., in renewables, or retraining, e.g., in the green economy. In contrast to studies that propose compensating for the inequality effects of trade [26], technological change [69] or socio-technical transitions [78-80], the rationale for these transfers may be purely pragmatic, i.e., to overcome political constraints to energy decarbonization. Since such compensating transfers could be expensive, depending on which country, government debt could be used to finance these costs and transfer them to future generations for whom much of the benefits of decarbonization will accrue [110]. Alternatively, in some cases or countries, government may be able to use command and control policies, that is regulate losers by legally obliging them to join transition partnerships and to behave in a certain way within those partnerships.

Second, to enable missing partnerships involving actors with low partnering capacity, government could use a combination of public investment and transfers. First, transfers could compensate actors for employing and training staff for partnering activities, attending events, covering reporting burdens, etc. The idea here is operating costs to partnering may restrict some actors, e.g., small NGOs, business, etc. from participating. Second, government investments may also be needed to build skills for partnering. This may include specialized training institutions [46,97], professional representatives for unrepresented groups or groups difficult to represent, e.g., future generations [111-115], or monitoring systems for evaluating partnering capacities and identifying deficiencies. These investments may be particularly important to ensure effective transformation partnerships. Some private organizations offer capacity building services for partnering, e.g., Global Development Incubator, the 2030 Agenda Partnership Accelerator. However, their emergence is recent, not tied to transformation partnerships and they tend to operate on a small scale.

Third, to alleviate the horizon problem, governments could use transfers financed by government debt to restructure the inter-temporal distribution of payoffs and incentivize actors with short-time horizons to participate in long-term partnerships for transformation, e.g., to deploy technologies or advance promising technologies. If much of the benefits of these partnerships accrue in the future, then debt finance that transfers this cost to future generations may be particularly important.

Fourth, coordinating missing partnerships requires overcoming several problems, e.g., information problems, various free-riding problems, etc. First, government could help by investing in platforms to identify and match potential partners, e.g., by using data mining, predictive analytics and tailored algorithms. There are similar suggestions to use ICT and digital platforms to strengthen major groups' engagement in the UN system [115,116] and in policy processes [117]. Second, government may need to invest in convening infrastructure, e.g., dialogues, deliberative processes, conferences, etc., to coordinate relevant partners, build networks and operationalize partnering activities. Third, governments may also require professional orchestrators to manage the process of partnering, ensure leadership, conflict management, trust building, etc., [61,62]. To some extent, UN agencies, international organizations and donor governments have developed orchestration capabilities, e.g., UNEP, the World Health Organization, the World Bank, various government ministries $[47,58]$. However, these capabilities are fragmented, limited and not based on a comprehensive strategy [58].

Fifth, one approach for dealing with mis-alignment problems is to delist such partnerships from relevant databases $[18,64]$. Already, UNDESA uses a traffic light system to flag non-reporting partnerships with clear delisting criteria. It may also be necessary to fine or ban partnerships involving blue washing activities or partnerships that maintain the status quo.

To summarize, due to problems with the voluntary approach, an entity is needed to orchestrate missing partnerships for transformation. This section suggests the most important instruments for implementing these partnerships are at the disposal of governments. Other entities such as UN 
agencies, etc., simply do not have the resources, legitimacy or policy capabilities to deal with these problems on a large scale.

\section{Concluding Discussion and Steps Forward}

Increasingly it is recognized that better frameworks are needed for partnerships [71]. There is a consensus that current frameworks are fragmented and rudimentary [45]. Partnership governance, often defined as meta-governance in the literature, refers to the "strategic steering and coordination of the partnership system" [63]. A tension in this literature exists over whether a bottom-up or top-down approach is more appropriate for partnerships (see Beisheim and Simon [71] for a recent review of this debate).

This paper identified five specific problems with the bottom-up approach: compensation for losers, partnering capacity, short-time horizons, insufficient coordination mechanisms and misaligned incentives. It was shown these problems can lead to a mismatch between the portfolio of bottom-up partnerships and the types of partnerships required for transformation, i.e., the bottom-up approach is not transformation effective. This finding suggests the bottom-up approach will deliver some, but not all, of the partnerships needed, and to achieve transformation, the approach must be complemented by a top-down approach that aims to assemble the remaining partnerships.

Policy tools governments could, in principle, use to alleviate each problem were outlined: transfers, public investment, regulation. It was suggested, given the scale of transformation required, governments may be best placed to act as (chief) orchestrator, compared to, for example, UN agencies, donor governments, or professional orchestrators, whose resources and decision tools may not suffice for orchestrating transformation. The extent to which government can improve the bottom-up framework is, of course, debatable, e.g., several difficulties with compensating transfers have been recognized, such as distortionary costs, weak commitment power, short-term budgetary constraints [65]. In addition, critical approaches have raised concerns about the ability of mainstream policy measures or tweaks to the system to adequately address transformations for achieving sustainability $[12,13]$.

There are two main problems specific to delivering missing transition partnerships. First, there is an identification problem. On the one hand, there needs to be wide agreement on the transition pathway or roadmap. Apart from energy decarbonization, in many areas, we are not clear what such a pathway/roadmap might look like. On the other hand, it is important to know what the correct portfolio of partnerships is for achieving this pathway. This is a difficult task and given the long-time scales involved, difficult to determine in advance.

Science could play a key role in furthering understanding of transformative pathways and partnerships needed for transformation. There is a considerable amount of research on transition pathways [8-11,32,55,56,73-75,118]; however, there is little work on the partnerships required to achieve such pathways. Drawing on Hummel et al. [119], this work could embrace trans-disciplinary approaches that link scientific research with partnership recommendations to address concrete transition problems. The top universities, researchers and international institutions could take leadership on this problem and focus on bottleneck problems in transitions and recommendations about keystone partnerships to address them.

Deliberative processes among diverse actors may be crucially important to facilitate a comprehensive and inclusive identification of partnerships for transformations and to provide support and legitimacy for implementing them. Participatory processes are experiencing a surge of popularity based on growing evidence on the capacity of diverse actors to make sound judgements in well-designed deliberative systems [120-122]. The Open Working Group (OWG) that negotiated the SDGs highlights how a well-designed intergovernmental deliberative process involving delegates and UN staff informed by stakeholders and expert inputs can deliver a comprehensive plan for action $[17,18]$

Second, there is the implementation problem. Transformations such as decarbonizing the world energy system cannot be effectively solved at national-level, international cooperation and a multi-level approach are required [12]. However, the current geopolitical climate is not conducive to global 
cooperation in many areas, e.g., energy, environment, trade, migration, nuclear non-proliferation. The case of decarbonization shows that several countries are captured by their government's fossil fuel interests, and it is questionable to what extent those governments could align themselves to transformation. On the other hand, even if we have the correct set of partnerships, much work remains to be done on ensuring their internal effectiveness, i.e., their ability to deliver on stated objectives.

The analysis of this paper suggests that implementation of missing partnerships should be government-led and involve stakeholders-states, civil society organizations and private sector entities-identified as relevant for transition partnerships. Policies-transfer payments, regulation and public investment-are likely needed to ensure the participation of key stakeholders and to address coordination and time-horizon problems. Overall, such an approach is well-aligned with the 2030 Agenda's Resolutions on Global Partnerships: led by governments that "bring together governments, civil society, the private sector, the UN system and other actors" to "encourage and promote (more) effective ... partnerships" [15].

To overcome the geopolitical climate, one approach could focus on building a coalition of governments/stakeholders, willing or already leading on the SDGs, to implement a multi-level framework for (missing) transformative partnerships. The framework could cover policies, infrastructure, platforms, deliberative procedures, etc., aimed at identifying and implementing transformative partnerships. Lessons can be learnt from existing frameworks, e.g., Kenya SDG Partnership Platform, SIDS Partnership Framework, Ghana Civil Society Organization (CSO) Partnerships Platform, etc. The framework should aim to cover the six SDG transformations and to identify and implement the missing transformative partnerships by transformation. The approach could work first with energy decarbonization, where there is already a mass of countries and actors working together on decarbonization. Later, the framework could be extended to other areas where transformations are required.

To encourage effectiveness, a transparent, accountable and participatory monitoring system could be developed to provide information on these partnerships and their performance. Many recommended practices can be applied to monitor transformative partnerships, e.g., online registries, strict registration criteria, detailed regular reporting, delisting of non-performing partnerships, etc. (cf. Beisheim and Simon $[64,71]$ for a summary of these recommendations). Furthermore, there could be a rating and reward system and a website tracking keystone transformation partnerships. Indeed, a stronger monitoring system seems more appropriate for missing transformative partnerships than for bottom-up partnerships where grassroot organizations and NGOs may lack resources for reporting.

Decarbonization is expected to yield many co-benefits, e.g., lower air pollution, improved health, new jobs and industries, improved energy access and energy security, lower energy poverty, reduced biodiversity loss, etc. [43,44]. Different co-benefits appeal to different countries and stakeholders. After several months observing informal inter-governmental negotiations on political declarations for sustainable development, it is relatively clear some countries see external development and climate mitigation as an internal security issue. For others, severe local air pollution provides a strong motivation to decarbonize. For others, reliance on fossil fuel imports significantly reduces their budgets for development investments. Others are motivated by the SDGs because of their founding role in developing them. In other countries, the renewable energy sector is becoming a significant private interest group. These differences provide a basis for building a coalition of governments.

Better partnership frameworks can help to harness the MoI for transformation and achieve an approach that integrates different resources, interests, responsibilities and perspectives [12,35]. The shift to voluntary agreements and Nationally Determined Contributions (NDCs) was an important recognition of the failure of binding global agreements on emissions. Energy decarbonization is focused on changing the world's energy system. Such transformations also need innovations in the social, economic, environmental and political systems underlying development [13]. The process of innovation itself does not require a global agreement to achieve it. Instead, it requires leadership and diffusion. 
Further scientific research on the internal success conditions of partnerships is also needed. The more stakeholders that participate in a partnership, often the greater the potential for failing. While there is much research on internal effectiveness, there are still many practical issues to address. For example, what activities maximize stakeholder engagement, learning and knowledge exchanges, what feedback mechanisms improve activities and uncover problems, how will conflicts be resolved and an equal distribution of power ensured, how will science-based tools be combined with stakeholder perspectives, how can proposals be assessed in an integrated way, what is the appropriate level, national or regional, to implement partnerships, what are appropriate decision-making mechanisms.

There is the question of to what extent the approach should be embedded in the UN. On the one hand, the UN could act as a neutral convener and has substantially more experience facilitating deliberative processes and working with partnerships/partnership frameworks than national governments $[45,59,64]$. If an intergovernmental process is initiated, member states involved generally have a vested interest in delivering an outcome. However, this outcome can differ in important ways from what was envisaged at the outset [17].

On the other hand, initiatives such as C40 Cities Climate Leadership Group, Carbon Pricing Leadership Coalition and Food, Agriculture, Biodiversity, Land and Energy (FABLE) initiative highlight how a bottom-up approach operating outside UN intergovernmental processes could be used to build a global network of governments and stakeholders [123,124]. Although such coalitions have some way to go to achieving their objectives, an important issue is whether a similar initiative for transformation partnerships could succeed in obtaining the participation and buy-in of governments.

More work on the details of the strategy is required. However, the broad elements outlined here should be kept in mind. The basic idea is to get a critical mass of government officials, ministers, delegates, negotiators, stakeholder groups, and their representatives, as well as scientists and experts and technical staff, working together on identifying and implementing keystone partnerships for achieving transformative transitions. In short, the future of the planet and the well-being of future generations may depend on it.

Funding: This project received funding from the European Commission and Irish Research Council Horizon 2020 research and innovation program under the Marie Sklodowska-Curie grant agreement 713279.

Acknowledgments: The author would like to thank participants at the United Nations Expert Group Meeting on Sustainable Development Goal 17 where some of the ideas of this paper were presented. I thank Patrick Paul Walsh, Chandrika Bahadur, Jeffrey Sachs and Yanis Ben Amor who provided a platform for this work to be realized. I would like to thank David O'Connor for helpful comments on an earlier draft. I also thank the editor and two anonymous reviewers for their suggestions regarding the improvement of the paper.

Conflicts of Interest: The author declares no conflict of interest.

\section{References}

1. Intergovernmental Science-Policy Platform on Biodiversity and Ecosystem Services. 2019 Global Assessment Report on Biodiversity and Ecosystem Services, A Summary for Policy Makers. 2019. Available online: https://www.ipbes.net/news/Media-Release-Global-Assessment (accessed on 15 May 2019).

2. Intergovernmental Panel on Climate Change. Summary for Policymakers. In Global Warming of $1.5^{\circ} \mathrm{C}$. An IPCC Special Report on the Impacts of Global Warming of $1.5^{\circ} \mathrm{C}$ Above Pre-Industrial Levels and Related Global Greenhouse Gas Emission Pathways, in the Context of Strengthening the Global Response to the Threat of Climate Change, Sustainable Development, and Efforts to Eradicate Poverty; World Meteorological Organization: Geneva, Switzerland, 2019.

3. World Economic Forum. Global Risks Report_-2019, 14th ed.; World Economic Forum: Geneva, Switzerland, 2019.

4. World Wide Fund for Nature. Living Planet Report-2018: Aiming Higher; Grooten, M., Almond, R.E.A., Eds.; WWF: Gland, Switzerland, 2018.

5. Luo, T.; Young, R.; Reig, P. Aqueduct Projected Water Stress Country Rankings; Technical Note; World Resources Institute: Washington, DC, USA, 2015; Available online: www.wri.org/publication/aqueduct-projectedwater-stresscountry-rankings (accessed on 15 March 2019).

6. World Bank. World Bank Group Climate Change Action Plan 2016-2020; World Bank: Washington, DC, USA, 2016. 
7. Hsiang, S.; Kopp, R.; Jina, A.; Rising, J.; Delgado, M.; Mohan, S.; Rasmussen, D.J.; Muir-Wood, R.; Wilson, P.; Oppenheimer, M.; et al. Estimating Economic Damage from Climate Change in the United States. Science 2017, 356, 1362-1369. [CrossRef] [PubMed]

8. United Nations Department for Economic and Social Affairs. Global Sustainable Development Report; Department of Economic and Social Affairs: New York, NY, USA, 2019; Forthcoming.

9. TWI2050-The World in 2050. Transformations to achieve the sustainable development goals; Report Prepared by The World in 2050 Initiative; International Institute for Applied Systems Analysis (IIASA): Laxenburg, Austria, 2018.

10. Sachs, J.D.; Schmidt-Traub, G.; Mazzucato, M.; Messner, D.; Nakicenovic, N.; Rockström, J. Six Transformations to achieve the Sustainable Development Goals. Nat. Sustain. 2019. [CrossRef]

11. Willet, W.; Rockstrom, J.; Loken, B.; Springmann, M.; Lang, T.; Vermeulen, S. Food in the Anthropocene: The EAT Lancet Commission on Healthy Diets from Sustainable Food Systems. Lancet 2019, 393, 447-492. [CrossRef]

12. Gorg, C.; Brand, U.; Haberl, H.; Hummel, D.; Jahn, T.; Liehr, S. Challenges for Social-Ecological Transformations: Contributions from Social and Political Ecology. Sustainability 2017, 9, 1045. [CrossRef]

13. Kramm, J.; Pichler, M.; Schaffartzik, A.; Zimmermann, M. Societal Relations to Nature in Times of Crisis-Social Ecology's Contributions to Interdisciplinary Studies. Sustainability 2017, 9, 1042. [CrossRef]

14. Hak, T.; Janouskova, S.; Moldan, B. Sustainable Development Goals: A need for relevant indicators. Ecol. Indic. 2016, 60, 565-573. [CrossRef]

15. United Nations. Transforming our World: The 2030 Agenda for Sustainable Development. In Outcome Document for the United Nations Summit to Adopt the Post 2015 Development Agenda; United Nations: New York, NY, USA, 2015.

16. United Nations. The Addis Ababa Action Agenda. In Outcome Document for the United Nations Third International Conference on Financing for Development; United Nations: New York, NY, USA, 2015.

17. Kamau, M.; Chasek, P.; O'Connor, D. Transforming Multilateral Diplomacy: The Inside Story of the Sustainable Development Goals; Routledge: New York, NY, USA, 2018.

18. Dodds, F.; Donoghue, D.; Roesch, J.L. Negotiating the Sustainable Development Goals; Routledge: New York, NY, USA, 2017.

19. Andonova, L.; Levy, M. Franchising global governance: Making sense of the Johannesburg type II partnerships. In Yearbook of International Cooperation on Environment and Development 2003/04; Stocke, O.S., Thomessen, O.B., Eds.; Earthscan: London, UK, 2003; pp. 19-31.

20. Backstrand, K. Multi-Stakeholder Partnerships for Sustainable Development: Rethinking Legitmacy, Accountability and Effectiveness. Eur. Environ. 2006, 16, 290-306. [CrossRef]

21. Pattberg, P.; Widerberg, O. Transnational multistakeholder partnerships for sustainable development: Conditions for success. Ambio 2016, 45, 42-51. [CrossRef] [PubMed]

22. United Nations. Millennium Development Goals Report. 2015. Available online: https://www.un.org/ millenniumgoals/2015_MDG_Report/pdf/MDG\%202015\%20rev\%20(July\%201).pdf (accessed on 20 March 2019).

23. United Nations Development Programme. Human Development Indicators and Indices: A Statistical Update. 2018. Available online: http://hdr.undp.org/sites/default/files/2018_human_development_statistical_update. pdf (accessed on 20 March 2019).

24. United Nations Development Programme. Human Development Report: Work for Human Development. 2015. Available online: http://hdr.undp.org/sites/default/files/2015_human_development_report.pdf (accessed on 20 March 2019).

25. Victor, D. Global Warming Gridlock: Creating more Effective Strategies for Protecting the Planet; Cambridge University Press: Cambridge, UK, 2011.

26. Antras, P.; de Gortari, A.; Itskhoki, O. Globalization, Inequality and Welfare. J. Int. Econ. 2017, 108, 387-412. [CrossRef]

27. Rajan, R. The Third Pillar: How Markets and the State Leave the Community Behind; Penguin Press: New York, NY, USA, 2019.

28. Austin, B.; Glaeser, E.; Summers, L. Saving the Heartland: Place-Based Policies in 21st Century America; Brookings Papers on Economic Activity Conference Draft; Harvard University: Spring, TX, USA, 2018.

29. OECD; SDSN. Long-term Pathways for the Implementation of the SDGs: The Governance Implications. Reflection Paper, 16 July 2019. 
30. Sachs, J.; Schmidt-Traub, G.; Kroll, C.; Lafortune, G.; Fuller, G. Sustainable Development Report 2019; Bertelsmann Stiftung and Sustainable Development Solutions Network (SDSN): New York, NY, USA, 2019.

31. Nilsson, M.; Griggs, D.; Visbeck, M. Policy: Map the Interactions between Sustainable Development Goals. Nature 2016, 534, 320-322. [CrossRef] [PubMed]

32. International Council for Science. A Draft Framework for Understanding SDG Interactions ICSU: 2016. Available online: http://bit.ly/sdg-interactions (accessed on 24 March 2019).

33. OECD. Governance as SDG Accelerator: Country Experiences and Tools; OECD Publishing: Paris, France, 2019.

34. Westman, L.; Broto, V.C. Climate governance through partnerships: A review of 150 urban initiatives in China. Global Environ. Chang. 2018, 50, 212-221. [CrossRef]

35. Huijstee, M.M.; Francken, M.; Leroy, P. Partnerships for sustainable development: A review of current literature. Environ. Sci. 2007, 4, 75-89. [CrossRef]

36. Clough, E.; Long, G.; Rietig, K. A Study of Partnerships and Initiatives Registered on the UN SDG Partnerships Platform. In An Independent Report Commission by the United Nations Department for Economic and Social Affairs (UNDESA); UNDESA: New York, NY, USA, 2019.

37. Andonova, L.; Betsill, M.; Bulkeley, H. Transnational climate governance. Glob. Environ. Polit. 2009, 9, 52-73. [CrossRef]

38. Bulkeley, H.; Andonova, L.; Bäckstrand, K.; Betsill, M.; Compagnon, D.; Duffy, R.; Kolk, A.; Hoffmann, M.; Levy, D.; Newell, P.; et al. Governing climate change transnationally: Assessing the evidence from a database of sixty initiatives. Environ. Plan. C Gov. Policy 2012, 30, 591-612. [CrossRef]

39. Glasbergen, P. Partnerships, Governance and Sustainable Development: Reflections on Theory and Practice; Glasbergen, P., Biermann, F., Mol, A., Eds.; Edward Elgar: Cheltenham, UK, 2007.

40. Pattberg, P.H.; Biermann, F.; Chan, S.; Mert, A. (Eds.) Public Private Partnerships for Sustainable Development. Emergence, Influence and Legitimacy; Edward Elgar: Cheltenham, UK, 2012.

41. Bauer, A.; Steurer, R. Multi-level governance ofclimate changeadaptation through regional partnerships in Canada and England. Geoforum 2014, 51, 121-129. [CrossRef]

42. Zeug, W.; Bezama, A.; Moesenfechtel, U.; Jahkel, A.; Thran, D. Stakeholders' Interests and Perceptions of Bioeconomy Monitoring Using a Sustainable Development Goal Framework. Sustainability 2019, 11, 1511. [CrossRef]

43. Nerini, F.F.; Sovacool, B.; Hughes, N.; Cozzi, L.; Cosgrave, E. Connecting climate action with other Sustainable Development Goals. Nat. Sustain. 2019, 2, 674-680. [CrossRef]

44. Nerini, F.F.; Tomei, J.; Seng To, L.; Bisaga, I.; Parikh, P. Mapping synergies and trade-offs between energy and the Sustainable Development Goals. Nat. Energy 2018, 3, 10-15. [CrossRef]

45. Beisheim, M.; Ellersiek, A. Partnerships for the 2030 Agenda for Sustainable Development. SWP Research Paper. RP 14, 2017. Available online: https://sustainabledevelopment.un.org/content/documents/ 24722017RP14_bsh_elk_01.pdf (accessed on 15 October 2018).

46. Martens, J. Multistakeholder Partnerships. In Future Models of Multilateralism? FES Occasional Paper; Friedrich Ebert Stiftung (FES): Berlin, Germany, 2007.

47. Hale, T.; Rogers, C. Orchestration and Transnational Governance. Rev. Int. Organ. 2014, 9, 59-82. [CrossRef]

48. Beisheim, M.; Liese, A. Transnational Partnerships: Effectively Providing for Sustainable Development? Palgrave Macmillan: Houndmills, UK, 2014.

49. Hale, T.; Mauzerall, D. Thinking globally and acting locally: Can the Johannesburg Partnerships coordinate action on sustainable development? J. Environ. Dev. 2004, 13, 220-239. [CrossRef]

50. UNDESA. In-depth Analysis of SIDS Partnerships; Department of Economics and Social Affairs: New York, NY, USA, 2019.

51. Widerberg \& Stipple. WIREs Clim. Chang. 2016, 7, 486-500. [CrossRef]

52. Beisheim, M.; Ellersiek, A.; Goltermann, L.; Kiamba, P. Meta-governance of Partnerships for Sustainable Development: Actors' Perspectives from Kenya. Pub. Admin. Dev. 2018, 38, 105-119. [CrossRef]

53. Abbott, K.W.; Genschel, P.; Snidal, D.; Zangl, B. International Organizations as Orchestrators; Cambridge University Press: Cambridge, UK, 2015.

54. Fowler, A.F. Authentic NGDO partnerships in the new policy agenda for international aid: Dead end or light ahead? Dev. Chang. 1998, 29, 137-159. [CrossRef]

55. SDSN. Roadmap to 2050: A Manual for Nations to Decarbonize by Mid-Century Technical Roadmap, 2019; Forthcoming. 
56. Deep Decarbonization Pathways Project. In Pathways to Deep Decarbonization 2015 Report; SDSN-IDDRI: New York, NY, USA, 2015.

57. Meuleman, L. Meta-governance for Sustainability: A Framework for Implementing the Sustainable Development Goals. In Routledge Studies in Sustainable Development, 1st ed.; Routledge: New York, NY, USA, 2018.

58. Klingebiel, D.; Paulo, S. Orchestration: An instrument for implementing the Sustainable Development Goals. In Briefing Paper 14/2015; German Development Institute: Bonn, Germany, 2015.

59. Dodds, F. Multi-Stakeholder Partnerships: Making Them Work for the Post-2015 Development Agenda; ECOSOC/United Nations: New York, NY, USA, 2015.

60. Bakhtiari, F. International Cooperative Initiatives at the United Nations Framework Convention on Climate Change. Clim. Policy 2018, 18, 655-663. [CrossRef]

61. Fowler, A.; Biekart, K. Multi-Stakeholder Initiatives for Sustainable Development Goals: The Importance of Interlocutors. Pub. Admin. Dev. 2017, 37, 81-93. [CrossRef]

62. Biekart, K.; Fowler, A. Comparative studies of multi-stakeholder initiatives: Volume I synthesis report: Country ownership_-building from within. Secretariat of the Task Team on CSO Development Effectiveness and Enabling Environment, International Institute of Social Studies: The Hague. Available online: http: //taskteamcso.com/activities/multi-stakeholder-initiatives-studies/ (accessed on 5 May 2016).

63. Visseren-Hamakers, I.J.; Arts, B.; Glasbergen, P. Partnership as Governance Mechanism in Development Cooperation: Intersectoral North-South Partnerships for Marine Biodiversity; Edward Elgar Publishing: Cheltenham, UK, 2007.

64. Beisheim, M.; Simon, N. Multi-stakeholder Partnerships for Implementing the 2030 Agenda: Improving Accountability and Transparency; Report Commissioned by UN DESA; Department of Economic and Social Affairs: New York, NY, USA, 2016.

65. Roland, G. The Political Economy of Transition. J. Econ. Perspect. 2002, 16, 29-50. [CrossRef]

66. Mirrlees, J.A. An exploration in the theory of optimum income taxation. Rev. Econ. Stud. 1971, 38, 175-208. [CrossRef]

67. Kaplow, B.L. Optimal Control of Externalities in the Presence of Income Taxation. Int. Econ. Rev. 2012, 53, 487-509. [CrossRef]

68. Hendren, N. Efficient Welfare Weights. NBER Working Paper 20351, July 2014.

69. Tsyvinski, A.; Werquin, N. Generalized Compensation Principle. NBER Working Paper 23509, June 2018.

70. United Nations. Towards Global Partnerships. In A Principle-Based Approach to Enhanced Cooperation Between the United Nations and all Relevant Partners; UN General Assembly, A/RES/70/224; UNGA: New York, NY, USA, 2015.

71. Beisheim, M.; Simon, N. Multistakeholder Partnerships for the SDGs: Actors' View on UN Metagovernance. Glob. Gov. 2018, 24, 497-515. [CrossRef]

72. Sachs, J.D. The Green New Deal is Feasible and Affordable. CNN, 28 February 2019.

73. Energy Transitions Commission. Mission Possible: Reaching Net-Zero Carbon Emissions from Harder-to-Abate Sectors by Mid-Century, Energy Transitions Commission. November 2018.

74. Davis, S.J.; Lewis, N.S.; Shaner, M.; Aggarwal, S.; Arent, D. Net Zero Emission Energy System. Science 2018, 360, 1419-1428. [CrossRef]

75. IRENA. Global Energy Transformation: A Roadmap to 2050 (2019 Edition); International Renewable Energy Agency: Abu Dhabi, UAE, 2019.

76. Lazard. Levelized Cost of Energy Analysis. Version 11.0. 2017. Available online: https://www.lazard.com/ media/450337/lazard-levelized-cost-of-energy-version-110.pdf (accessed on 15 May 2019).

77. Sachs, J.D. The Green New Deal isn't Outlandish-It's a Necessity. Washington Post, 3 April 2019.

78. Sovacool, B.K. What are we doing here? Analyzing fifteen years of energy scholarship and proposing a social science research agenda. Energy Res. Soc. Sci. 2014, 1, 1-29. [CrossRef]

79. Sovacool, B.K.; Dworkin, M.H. Energy justice: Conceptual Insights and Practical Applications. Appl. Energy 2015, 142, 435-444. [CrossRef]

80. Jenkins, K.; McCauley, D.; Heffron, R.; Stephan, H.; Rehner, R. Energy justice: A conceptual review. Energy Res. Soc. Sci. 2016, 11, 174-182. [CrossRef]

81. Hope, C.; Anderson, J.; Wenman, P. Policy Analysis of the Greenhouse Effect: An Application of the PAGE Model. Energy Policy 1993, 23, 327-338. [CrossRef]

82. Nordhaus, W.D. Managing the Global Commons: The Economics of Climate Change; MIT Press: Cambridge, MA, USA, 1994. 
83. International Energy Agency. World Energy Outlook 2017. Available online: https://www.iea.org/weo2017/ (accessed on 5 March 2019).

84. Revesz, R.L.; Howard, P.H.; Arrow, K.; Goulder, L.H.; Kopp, R.E.; Livermore, M.A.; Oppenheimer, M.; Sterner, T. Global Warming: Improve Economic Models of Climate Change. Nature 2014, 508, 173-175. [CrossRef]

85. Stiglitz, J.E.; Stern, N.; Duan, M.; Edenhofer, O.; Giraud, G.; Heal, G.M.; la Rovere, E.L.; Morris, A.; Moyer, E.; Pangestu, M.; et al. High-Level Commission on Carbon Prices. In Report of the High-Level Commission on Carbon Prices; License: Creative Commons Attribution CC BY 3.0 IGO; World Bank: Washington, DC, USA, 2017.

86. Mastrandrea, M.D. Representation of climat impacts in integrated assessment models. In Assessing the Benefits of Avoided Climate Change: Cost-Benefit Analysis and Beyond; Gulledge, J., Richardson, L.J., Adkins, L., Seidel, S., Eds.; Pew Center on Global Climate Change: Arlington, VA, USA, 2010; pp. 85-99.

87. Dohmen, F.; Jung, A.; Schultz, S.; Traufetter, G. German Failure on the Road to a Renewable Future, Der Spiegel. May 2019. Available online: https://www.spiegel.de/international/germany/german-failure-onthe-road-to-a-renewable-future-a1266586.html (accessed on 15 August 2019).

88. Sachs, J.D. For Climate Safety, Call in the Engineers. Project Syndicate, 20 December 2018.

89. Erickson, P.; Lazarus, M. Assessing the Greenhouse Gas Emissions Impact of New Fossil Fuel Infrastructure; Stockholm Environment Institute: Seattle, WA, USA, 2013.

90. Erickson, P.; Lazarus, M.; Tempest, K. Carbon Lock-in From Fossil Fuel Supply Infrastructure; Stockholm Environment Institute: Seattle, WA, USA, 2015.

91. Seto, K.C.; Davis, S.J.; Mitchell, R.B.; Stokes, E.C.; Unruh, G.; Ürge-Vorsatz, D. Carbon lock-in: Types, causes, and policy implications. Annu. Rev. Environ. Resour. 2016, 41, 425-452. [CrossRef]

92. Geels, F.W.; Sovacool, B.K.; Schwanen, T.; Sorrell, S. Sociotechnical transitions for deep decarbonization. Science 2017, 357, 1242-1244. [CrossRef]

93. Tong, D.; Zhang, Q.; Zheng, Y.; Caldeira, K.; Shearer, C.; Hong, C.; Qin, Y.; Davis, S.J. Committed emissions from existing energy infrastructure jeopardize $1.5^{\circ} \mathrm{C}$ climate target. Nature 2019. [CrossRef]

94. York, R.; Bell, S.E. Energy transitions or additions? Why a transition from fossil fuels requires more than the growth of renewable energy. Energy Res. Soc. Sci. 2019, 51, 40-43. [CrossRef]

95. Mazzucato, M. Mission-Oriented Innovation Policy: Challenges and Opportunities; Working Paper IIPP WP 2018-01; UCL Institute for Public Purpose: London, UK, 2017.

96. Kattel, R.; Mazzucato, M.; Ryan-Collins, J.; Sharpe, S. The Economics of Change: Policy Appraisal for Missions, Market Shaping and Public Purpose; Working Paper IIPP WP 2018-06; UCL Institute for Innovation and Public Purpose: London, UK, 2018.

97. UN Department of Economic and Social Affairs. Partnership Exchange: Advancing the Global Partnerships for Sustainable Development 2018 Report. 2018. Available online: https://sustainabledevelopment.un.org/ content/documents/2569Partnership_Exchange_2018_Report.pdf (accessed on 11 April 2019).

98. Liese, A.; Beisheim, M. Transnational Public-Private Partnerships and the Provision of Collective Goods in Developing Countries. In Governance Without a State? Policies and Politics in Areas of Limited Statehood; Risse, T., Ed.; Columbia University Press: New York, NY, USA, 2011; pp. 115-143.

99. Stibbe, D.T.; Reid, S.; Gilbert, J. Maximising the Impact of Partnerships for the SDGs; The Partnering Initiative and UN DESA: New York, NY, USA, 2018.

100. UNDP. Multi-Stakeholder Engagement Processes: A UNDP Capacity Development Resource; Conference Paper \#7, Working Paper; Capacity Development Group, Bureau for Development Policy, United Nations Development Programme: New York, NY, USA, November 2006.

101. Jenkins, K.; McCauley, D.; Forman, A. Energy justice: A policy approach. Energy Policy 2017, 109, 825-834. [CrossRef]

102. Sovacool, B.K.; Burke, M.; Baker, L.; Kotikalapudi, C.K.; Wlokas, H. New frontiers and conceptual frameworks for energy justice. Energy Policy 2017, 105, 677-691. [CrossRef]

103. Arrhenius, G. The Democratic Boundary Problem Revisted. Ethics Politics Soc. J. Moral Political Philos. 2018, 1, 89-122.

104. Berliner, D.; Prakash, A. Bluewashing" the Firm? Voluntary Regulations, Program Design, and Member Compliance with the United Nations Global Compact. Policy Stud. J. 2015, 43, 115-138. [CrossRef]

105. Fowler, A. Innovation in Institutional Collaboration: The Role of Interlocutors; Working Paper, 584; International Institute of Social Studies, Erasmus University: Rotterdam, The Netherlands, 2014. 
106. Tulder, R.; Keen, N. Capturing Collaborative Challenges: Designing Complexity-Sensitive Theories of Change for Cross-Sector Partnerships. J. Bus. Ethics 2018, 150, 315-332. [CrossRef] [PubMed]

107. Abbott, K.W.; Hale, T. Orchestrating global solution networks: A guide for organizational entrepreneurs. Innov. Technol. Gov. Glob. 2014, 9, 195-212.

108. Biermann, F.; Chan, M.; Mert, A.; Pattberg, P. Multi-Stakeholder Partnerships for Sustainable Development: Does the Promise Hold? In Partnerships for Sustainable Development; Reflections on Theory and Practice; Glasbergen, P., Biermann, F., Mol, A., Eds.; Edward Elgar: Cheltenham, UK, 2007.

109. Backstrand, K. Are partnerships for sustainable development democratic and legitimate? In Public-Private Partnerships for Sustainable Development: Emergence, Influence and Legitimacy; Pattberg, P., Biermann, F., Chan, S., Mert, A., Eds.; Edward Elgar: Northampton, MA, USA, 2012.

110. Sachs, J. Climate Change and Intergenerational Well-being. In Oxford Handbook of the Macroeconomics of Global Warming; Lucas, B., Willi, S., Eds.; Oxford University Press: Oxford, UK, 2015.

111. Saijo, T. "Future Design: Concept for a Ministry of the Future", Social Design Engineering Serie; Kochi University of Technology: Kochi, Japan, 2015.

112. Kamijo, Y.; Komiya, A.; Mifune, N.; Saijo, T. Negotiating with the future: Incorporating imaginary future generations into negotiations. Sustain. Sci. 2017, 12, 409-420. [CrossRef] [PubMed]

113. Hara, K.; Yoshioka, R.; Kuroda, M.; Kurimoto, S.; Saijo, T. Reconciling Intergenerational Conflicts with Imaginary Future Generations - Evidence from a Participatory Deliberation Practice in a Municipality in Japan. Social Design Engineering Series; Kochi University of Technology: Kochi, Japan, 2017.

114. Shahrier, S.; Kotani, K.; Saijo, T. Intergenerational sustainability dilemma and the degree of capitalism in societies: A field experiment. Sustain. Sci. 2017, 12, 957-967. [CrossRef]

115. Adams, B.; Pingeot, L. Strengthening Public Participation at the United Nations for Sustainable Development: Dialogue, Debate, Dissent, Deliberation. A Report commission by the UN DESA Major Groups Programme. Available online: https:/www.globalpolicy.org/images/pdfs/images/pdfs/UNDESA_MGs_Report.pdf (accessed on 30 June 2019).

116. Afzalan, N.; Muller, B. Online Participatory Technologies: Opportunities and Challenges for Enriching Participatory Planning. J. Am. Plan. Assoc. 2018, 84, 162-177. [CrossRef]

117. Walsh, P.P. Implementing the UN 2030 Sustainable Development Agenda in Ireland: A Case for Hybrid Sustainable Development Parliamentary Committees. Irish Stud. Int. Aff. 2016, 27, 9-19. [CrossRef]

118. FABLE. Pathways to Sustainable Land-Use and Food Systems. 2019 Report of the FABLE Consortium. Laxenburg and Paris: International Institute for Applied Systems Analysis (IIASA) and Sustainable Development Solutions Network (SDSN), Paris, 2019. Available online: http://unsdsn.org/wp-content/ uploads/2019/07/2019-FABLE-Report_Full_High-Resolution.pdf (accessed on 14 August 2019).

119. Hummel, D.; Jahn, T.; Keil, F.; Liehr, S.; Stieb, I. Social Ecology as Critical, Transdisciplinary Science—Concepualizing, Analyzing and Shaping Societal Relations to Nature. Sustainability 2017, 9, 1050. [CrossRef]

120. Dryzek, J.S.; Bachtiger, A.; Chambers, S.; Cohen, J.; Druckman, J.N.; Felicetti, A.; Fishkin, J.S.; Farrell, D.M.; Fung, A.; Gutmann, A.; et al. The Crisis of Democracy and Science of Deliberation. Science 2019, 363, 1144-1146. [CrossRef] [PubMed]

121. Farrell, D.M.; Suiter, J.; Harris, C. Systematizing' constitutional deliberation: The 2016-18 citizens' assembly in Ireland. Irish Political Stud. 2019, 34, 113-123. [CrossRef]

122. Walsh, P.P.; Murphy, E.; Horan, D.; Banerjee, A. The UN High-Level Political Forum and Parliamentary Governance for Sustainable Development; SPIRE Working Paper WP14; School of Politics \& International Relations, UCD: Dublin, Ireland, 2019.

123. Carbon Pricing Leadership Report 2018/19; License: Creative Commons Attribution CC BY 3.0 IGO; World Bank: Washington, DC, USA, 2019.

124. Schmidt-Traub, G.; Obersteiner, M.; Mosnier, A. Fix the Broken Food System in Three Steps. Nature 2019, 569, $181-183$. [CrossRef] [PubMed]

(C) 2019 by the author. Licensee MDPI, Basel, Switzerland. This article is an open access article distributed under the terms and conditions of the Creative Commons Attribution (CC BY) license (http://creativecommons.org/licenses/by/4.0/). 